\title{
Impact of the worldwide trends on the development of the digital economy
}

\section{ВЛИЯНИЕ ГЛОБАЛЬНЫХ ТЕНДЕНЦИЙ НА РАЗВИТИЕ ЦИФРОВОЙ ЭКОНОМИКИ}

\section{Impacto de las tendencias mundiales en el desarrollo de la economía digital}

Received: June 9, 2020

\section{Abstract}

The aim of the article is to develop a new model of the digital economy as a new scientific direction of the philosophy of economics. Analysis methodology is the use of methods such as crosscultural, systemic, synergetic, informational, axiological, cybernetic to develop a new model of the digital economy as a new scientific direction, in the context of which a new information space is being formed. The problems of solving the digital economy are taking place against the backdrop of new trends - globalization 4.0, Industry 4.0, Enlightenment 2.0, Agile management, in the context of which there is a transition from simple interconnection to hyperconnection and the spread of Moore's law, according to which there is a doubling of information. The results of the study. 1) The development of the digital economy as a new scientific field, which is based on a combination of concepts of informatization, digitalization, robotics, developing under the influence of global trends is studied. 2) It has been established that the digital economy contributes to technological progress and, under the pressure of global trends, develops a variety of economic models of scientific, technical and digital progress,
Accepted: August 11, 2020

Written by:

Voronkova Valentyna H. ${ }^{31}$ https://orcid.org/0000-0002-0719-1546

Nikitenko Vitalina A. ${ }^{32}$ https://orcid.org/0000-0001-9588-7836

Teslenko Tatyana V.33 https://orcid.org/0000-0002-5810-3569

Bilohur Vlada E. ${ }^{34}$ https://orcid.org/0000-0001-9041-7050

\section{Аннотация}

Цель - разработка новой модели цифровой экономики как нового научного направления философии экономики. Методология анализа - использование методов кросскультурного, системного, синергетического, информациологического, аксиологического, кибернетического для разработки новой модели цифровой экономики как нового научного направления, в контексте которого происходит формирование нового информационного пространства. Проблемы решения цифровой экономики происходят на фоне новых тенденций - глобализации 4.0, INDUSTRY 4.0, Просветительства 2.0, Agileменеджмента, в контексте которых происходит переход от простой взаимосвязи к гиперсвязи и распространения закона Мура, согласно которого происходит удвоение информации. Результаты исследования. 1) Исследовано развитие цифровой экономики как нового научного направления, в основе которого находится соединение концепций информатизации, цифровизации, роботизации, развивающиеся под влиянием

\footnotetext{
${ }^{31}$ Doctor of Philosophy, Professor, Academician of the Ukrainian Academy of Political Sciences, Head of the Department of Management of Organizations and Project Management, Engineering Institute of Zaporizhzhia National University (Ukraine, Zaporizhzhia).

32 PhD in Philosophy, Associate Professor, Associate Professor of the Department of Management of Organizations and Project Management, Engineering Institute of Zaporizhzhia National University (Ukraine, Zaporizhzhia).

${ }^{33}$ Associate Professor of the Department «Economics and management», Dnepropetrovsk National University of Railway Transport Named after Academician V. Lazaryan (DNUZT) (Ukraine, Dnipro)

34 Doctor of Philosophy, Professor, Head of the Department of Theory and Methodology of Physical Education and Sport Disciplines, Bogdan Khmelnitsky Melitopol State Pedagogical University (Ukraine, Melitopol).
} 
which are based on the solution of problems of man, science, society. 3) The problematic issues of the digital economy and the conditions for its solution are identified. Conclusions. The prospects that the digital economy opens up thanks to modern technologies representing a technological breakthrough are analyzed. The digital technology network is designed so that it moves with the least loss and the smallest pieces of calculus are at the heart of this new constant flow system. All this indicates that in the context of globalization and the BIG DATA era, humanity is entering a new stage of calculus, when information doubles in accordance with Moore's law.

Key Words: global trends, digital economy, information-digital technologies, philosophy of economics. глобальных тенденций. 2) Установлено, что цифровая экономика содействует технологическому прогрессу и под давлением глобальных тенденций развивает разнообразные экономические модели научно-технического и цифрового прогресса, в основе которых - решение проблем человека, науки, общества. 3) Определены проблемные вопросы цифровой экономики и условия еe решения. Выводы. Проанализированы перспективы, которые открывает цифровая экономика благодаря современным технологиям, представляющим технологический прорыв. Сеть цифровых технологий создана таким образом, чтобы они перемещались с наименьшими потерями и в основе этой новой системы постоянного потока лежали самые мелкие частички исчислений. Все это свидетельствует о том, что в условиях глобализации и эпохи BIG DATA человечество входит в новый этап исчислений, когда информация удваивается в соответствии с законом Мура.

Ключевые слова: глобальные тенденции, цифровая экономика, информационноцифровые технологии, философия экономики.

\section{Resumen}

El objetivo del artículo es desarrollar un nuevo modelo de economía digital como una nueva dirección científica de la filosofía de la economía. La metodología de análisis es el uso de métodos como el transcultural, sistémico, sinérgico, informativo, axiológico, cibernético para desarrollar un nuevo modelo de economía digital como una nueva dirección científica, en el contexto del cual se está formando un nuevo espacio de información. Los problemas de resolución de la economía digital se están produciendo en el contexto de nuevas tendencias: globalización 4.0, Industria 4.0, Ilustración 2.0, Gestión ágil, en cuyo contexto hay una transición de la interconexión simple a la hiperconexión y la difusión de la ley de Moore. según el cual hay una duplicación de información. Los resultados del estudio. 1) Se estudia el desarrollo de la economía digital como un nuevo campo científico, que se basa en una combinación de conceptos de informatización, digitalización, robótica, desarrollándose bajo la influencia de tendencias globales. 2) Se ha establecido que la economía digital contribuye al progreso tecnológico y, bajo la presión de las tendencias globales, desarrolla una variedad de modelos económicos de progreso científico, técnico y digital, los cuales se basan en la solución de problemas del hombre, la ciencia, sociedad. 3) Se identifican los temas problemáticos de la economía digital y las condiciones para su solución. Conclusiones. Se analizan las perspectivas que abre la economía digital gracias a las tecnologías modernas que representan un avance tecnológico. La red de tecnología digital está diseñada para que se mueva con la menor pérdida y las piezas más pequeñas de cálculo estén en el corazón de este nuevo sistema de flujo constante. Todo esto indica que en el contexto de la globalización y la era de BIG DATA, la humanidad está entrando en una nueva etapa del cálculo, cuando la información se duplica de acuerdo con la ley de Moore.

Palabras clave: tendencias globales, economía digital, tecnologías de la información digital, filosofía de la economía.

\section{Introduction}

The relevance of the research topic is that in the current conditions of the digital economy development, as a new scientific direction, there is an influence of global tendencies of humanity, namely: informatization, digitization, robotization. At the heart of these trends is a 


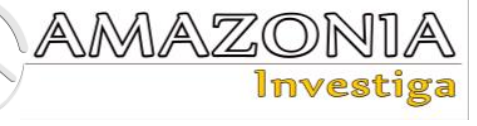

combination of philosophical, economic, environmental, socio-political, spiritualaxiological and moral principles of the information society, requiring the involvement of laws governing the development of production, distribution, exchange and consumption based on the development of information and communication technologies (hereinafter - ICT) in a postclassical context (Report of the Roman Club, 2019, p.13). Exploring the philosophy of the digital economy is extremely important because the modern economy is in a state of chaos and instability, the previous laws do not work because they have led to financial, tax, environmental and other crises since 2008, as a result the classical economy must be supplemented by information (digital) one, through which humanity can get out of the crisis), information support system for regional human resource development (Mamatov, Konstantinov, Mashkova \& Savina, 2019, p. 426-427). The huge budget deficits, determined by crises and corruption, which have a negative impact on economic growth, are forcing the government, under the pressure of global trends, to develop diverse economic models of scientific technology and digital progress, which are based on the solution of human problems, humanism, science, social security which will reduce the problems of social instability. Classical economic science has not been able to solve the problems of deepening inequality, reducing the level of welfare of citizens, increasing instability in all sectors of the economy. Many of these problems are at the intersection of philosophy and economics, morality and politics, so the development of the digital economy concept as a new scientific direction of economic philosophy, which is a strategic direction for the development of both philosophical and economic science, is of particular relevance and practical importance (Sadovnicova \& Kokiel, 2020, p.153-159). Therefore, in conditions of the development of humankind global tendencies, particularly globalization 4.0, scientific researches directed on the analysis of new problems of technological progress, aimed at further improvement of digital society, digital culture and digital technologies, should be considered relevant

\section{Literature review}

In the article, we focus our attention on the problems analysis of the digital economy development as a new scientific direction, which is based on the combination of the processes of informatization, robotization, digitalization, developing under the influence of global trends. This is the analysis of such works as Brinolfsson
E.\& Makafi E. "The Second age of machines: work, progress and prosperity in the times of emergency" (2016), Kelly Kevin "Inevitable. 12 technologies that shape our future" (2018), as well as McAfee Andrew and Brynolfsson Eric "Machine, platform, crowd. How to Tame Our Future" (2019). Analysis of the literature shows that digitalization is becoming a leading direction of scientific and technological progress, which transforms reality and affects our entire life. Among the achievements of digitalization is the emergence of a computer, a robot and digital solutions as catalysts for increasing the physical and intellectual capabilities of a person. We also analyzed articles that were published in the Amazonia Investiga magazine, namely the articles by Getman, A., Danilyan, O., Dzeban, A., Kalinovsky, Y. \& Hetman, Y. "Information security in modern society: Sociocultural aspects "(Amazonia Investiga, 2019), as well as the works of Goodman Mark "Crimes of the Future" (2019), which draw attention to such an important problem as ensuring information security in the context of sociocultural and other aspects that should work in a digital society and contribute to the progress of society. Mark Gookdman, as one of the world's leading authorities on global security, shows the downside of technological innovation and the consequences that non-compliance with national security can lead to. Literature analysis of such authors as Mason Paul "Post-capitalism. A guide to the future" (2019), McAfee Andrew \& Brynolfsson Eric "Machine, platform, crowd. How to tame our future" (2019), O'Reilly Tim“" Who knows what the future will be like" (2018), Pinker Stephen“ Enlightenment today. Arguments in favor of reason, science and progress" ( 2019), as well as Reinert Eric S. How Rich" Wealth Enriched... and why poor countries remain poor "(2018) suggests that countries that are awaiting an" economic miracle "and those that have achieved it should develop digital progress, intellectual capitalism, digital economy and digital management because they count on economic success, they achieve it and become new leaders. These works note that with the development of computer power, the digital potential of mankind also increases, which should be embedded in new scientific economic and managerial directions, to which we also refer to the philosophy of economics. The article by Mamatov, A., Konstantinov, I., Mashkova, A. \& Savina, O. "Information support system for regional human resource development (Amazonia Investiga, 2019), which focuses on the problem of the formation of a human resource at the regional level, where it is noted that the human resource has a huge production and 
intellectual potential necessary for the development of the digital economy and digital society was also of great interest for us. An important methodological role for our analysis was played by the articles by Tsvetkov, V., Shaytura, S., Feoktistova, V., Minitaeva, A., Kozhaev, Y. \& Belyu, L. "Metamodelling in the information field" (Amazonia Investiga, 2020), which studies meta-relations in the information field, information situations that characterize meta-relations: a research situation, a transformation situation, a generalization situation, as well as the work of Tsvetkov, V., Shaytura, S., Feoktistova, V., Minitaeva, A., Kozhaev, Y., \& Belyu, L. "Metamodelling in the information field. (Amazonia Investiga, 2020), which deeply considers the situational and normative approach, which is to take into account the situation for each country in a wide social and economic context, as well as Levitin Daniel's work "Structured thinking. A clear mind in information chaos" (2020), which sets us up for the formation of structured thinking and that the mind must win in the context of globalization and digital development of society. We came to the conclusion that the digital economy promotes technological progress and, under the pressure of global trends, develops various economic models of scientific, technological and digital progress, based on the solution of problems of man, science, society, including the development of such a direction as the philosophy of economics. For generalization of the meta-conclusions, the articles by Andriukaitiene, R., Ernestas, J. \& Voronkova, V. "The concept of corporate social responsibility and its implementation in the activity of organizations" (2019), Cherep, A., Voronkova, V., Muts, L. \& Fursìn, A. "Information and innovation technologies as a factor of improving the efficiency of digital economy and business in the globalization 4.0" (2019), Kyvliuk, O., Andriukaitiene, R., Voronkova, V. \& Nikitenko, V. "Sustainable Development of Organizations. Innovative Approach and Social Responsibility (2018). As a result of analyzing such an extensive, relevant and sufficiently innovative literature, we came to the conclusion that the digital economy, thanks to modern technologies, represents a technological breakthrough, the revolution of "bots" will change our world in the near future, therefore, the newest directions of "philosophy of economics" should be developed, on which is based the influence of global trends on the development of the digital economy.

\section{Research purpose and tasks}

The study aims at identifying the theoretical and practical basics of the digital economy as a new scientific direction, evolving in the context of a philosophy of economics, based on an interdisciplinary approach and combines many sciences - philosophy and economics, politics and ecology, religion and morality and defining peculiarities of existing economic phenomena and processes in the dynamic and chaotic world of globalization.

To study the set goal, the following tasks were solved:

- to determine the theoretical basics of the influence of new trends in informatization, digitization, robotization, which are developing under the influence of the world global development on the features of the digital economy functioning, which is a complex social and economic phenomena and dynamic process;

- to analyze new trends that completely change the digital world due to the impact of information and communication technologies, which actively, effectively and efficiently influence their implementation in life;

- to consider economic synergy as a methodological basis for the digital economy and a new scientific direction;

- to analyze the new foundations of the information economy, which expands the possibilities of the dichotomy "spirit / mind - body", previously restricted both by society and by man.

\section{Materials and methods}

- The goal is the development of a new model of the digital economy as a new scientific direction of the philosophy of economics

- The subject is the development of the digital economy as a new scientific direction of modern philosophy.

- The object is the influence of global trends on the development of the digital economy as a new scientific direction of philosophy of economics.

- Research Objectives:

- to study the impact of new trends informatization, digitalization, robotization, which are developing under the influence of global development of the world and affect the peculiarities of the digital economy functioning, which is a complex social and economic phenomena and dynamic process; 


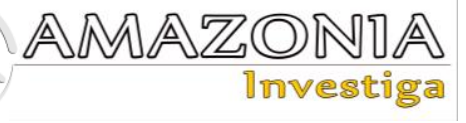

- to creation a new model of the digital economy as a new scientific direction of the philosophy of economics for its further filling with information and creative meanings in the context of counteracting negative trends in globalization, informatization, technologization, digitalization;

- to develop a methodology model of a creative economy, which requires the study of global trends, the formation of new digital thinking and a new digital culture.

The method of cross-cultural analysis is aimed at identifying global trends in the study of the digital economy model, its structural components and their functions in terms of their transformation; exploring the philosophy of economics as a complex social, cultural and economic phenomenon, and developing such aspects of a digital economy model that would capture the newness of technology aimed at growing new trends caused by systemic digital change that require digital operational upgrades, step-by-step improvements and smooth progress. The system analysis method allows us to consider the digital economy model as a complex self-organized system with several subsystems that need to fill the model with content that would contribute to a new way of interacting with the Internet revolution, which opens up many new opportunities for humans. Nowadays, cloudbased companies are using neural networks on GPUs every day, and cloud-based artificial intelligence is becoming an integral part of everyday life. The system method helps to consider the model of digital economy as a complex self-organized system consisting of a number of subsystems, each of which is characterized by integrity, structure, interaction between the system and environment, autonomy, adaptability, hierarchy, uniqueness of systems, multiplicity. The digital economy holds on to the free flow of copies.

The use of the synergistic method makes it possible to explain the features of the digital economy model in normal and catastrophic modes, which require a transition to sustainable development, as a basis for updating the conditions to which the complexity methodology can be applied. The synergistic methodology that makes a major contribution to the digital economy in the context of globalization includes the theory of chaos, dissipation (energy dissipation), bifurcation, and attractor search (attraction points). Today, such a point of attraction in the context of globalization is the Internet, which by 2025 will cause the global economy to rise by at least $\$ 6.2$ trillion (Goodman, 2019, p. 331).

In the context of the information-technology approach, the model of digital economy as a geopolitical, geo-economic, geocultural phenomenon of the globalization period, as a result of which all physical objects will receive a certain IT-address and thus become a part of information technology is being formed. Things that were previously "mute" have a voice, and each entity can tell its own story. An updated Internet will make it possible to remotely control any object on Earth.

The axiotic approach considers the digital economy model in the broad civilizational context of values, which is the transformation of the universal into the special and the special into the universal. New values of bits from the digital realm merge with atoms of the physical world, each of which will have identity and existence in both worlds, both physical and virtual, and the difference between online and offline will disappear. These processes underpin the values of digital culture as a condition for human existence in a digital society: the Second age of machines: work, progress and prosperity in the times of emergency technologies (Brinolfsson \& Makafi, 2016, p.7).

A cybernetic approach to the management of educational system that distinguishes structural components as input parameters, which is based on the governing body, the entity and the entity, the output, feedback. Optimal control is achieved by a homeostatic equilibrium that contributes to achieving its goals and effectiveness: the concept of corporate social responsibility and its implementation in the activity of organizations (Andriukaitiene, Ernestas \& Voronkova, 2019, p.184-185).

Globalization, the new digital era, the Industrial Revolution (Industry 4.0), which is addressing the challenges of global governance, is thinking in the categories of complex systems. The methodology used for this analysis is the Agile methodology as a methodology for researching a society of complexity. It is hypothesized that digital technologies are emerging at the heart of the digital economy model that emerges from the digitalization of the world, which penetrates into all spheres of human life. Digital technologies are the main driving force behind human development, transforming entire industries (Tsvetkov, Shaytura, Feoktistova, Minitaeva, Kozhaev \& Belyu, 2020, p. 395-402). 


\section{Analysis of research results}

Theoretical basics of the influence of new trends - informatization, digitalization, robotization, which are developing under the influence of global development of the world and affect the peculiarities of the digital economy functioning, which is a complex social and economic phenomena and dynamic process. The modern world is indeed in a critical state and we feel the need to develop a new ideology, concept or even paradigm for the philosophy of economy, which could solve all problems, form the prerequisites for the transition to domination of the information (digital) economy in all spheres of a society life that produces new, innovative approaches to a man, nature, economy, society based on the ideals of the anthropologichumanistic dimension of human civilization, elimination of the deep crisis of values, formation of a stable future it, economic wellbeing and prosperity. In order to achieve the goals of digital civilization, it is necessary to achieve "a balance between man and nature, short and long term prospects, common and personal interests, the introduction of information and communication technologies that are really beneficial as they can attract investors and support long term solutions" (Cherep, Voronkova, Muts \& Fursìn, 2019, p.169).

The philosophy of economics, with its object and subject of study - the digital economy - requires the analysis of trends, namely informatization, digitization, robotization, which are under the influence of global development of the world, and the last one, as already noted, is a complex social and economic phenomena and dynamic process. Thus, digital economy as a new scientific direction of philosophy of economics in the context of theoretical foundations of detection new trends of influence helps to uncover new laws of market economy, globalization 4.0, "new Enlightenment 2.0", "flexible-Agile management" that determine the development and implementation of new trends informatization, digitization, robotization, and illuminates our world beyond recognition. New laws and trends of the information-digital society are aimed at making society and people were rational and economically efficient, overcoming the ecological and economic crisis, developing the human development index and achieving sustainable development (Kyvliuk Andriukaitiene, Voronkova \& Nikitenko, 2018, p. 63-64).
In order for this to happen, society must be based on innovations and innovative development, an efficient infrastructure, society should move towards information technology, for prosperity and well-being, the last one also related to computers (the term "Computer welfare" has appeared not occasionally). However, there is the troubling fact that there is no country in the world that exhibits high socio-economic and information-innovation development (the human development index is above 0.8 ) and at the same time has reached sustainable indicators (less than $1.8 \mathrm{ha})$ when measuring its environmental footprint. This means that is no country in the world with high level of productivity on all four pillars of development (economic, social, environmental, information-digital), and therefore the necessary positive digital breakthrough is noted by Ernst Ulrich von Weizsecker and Anders Wykman in the work "Come on! Capitalism, shortsightedness, population and the destruction of the planet. Report of the Roman Club" (Report of the Roman Club, 2019, p.13).

New trends that totally change the digital world through information and communication technologies that actively, effectively and efficiently influence their implementation in life. A very balanced and generally optimistic view on informatization, digitization, digitalization, restoration of valuable resources, especially for breakthrough technologies and their benefit to the well-being of a human and society, was presented by Pinker Stephen (Pinker, 2019) who emphasized the big positive role of big data (Big Data) for society and all sectors of economy, including the energy transition and the circulating economy, based on the above trends. All these processes are recorded and analyzed in such a new direction as the philosophy of economics, the central core of which is the digital economy. The ICT revolution has overcome far greater distances, which are limited by information sharing and methods of modeling and cognition of complex systems. The whole industrial sector is now making an interesting transition to "Industry 4.0", built on a completely different type of progress - informational driven by information technologies, big data, information democracy, built in turn on information technologies. In some places, this has been practiced for a long time, and "direct democracy" is nowadays much easier to spread, at least technically, through the large number of social media platforms that are also a part of the ICT revolution. 


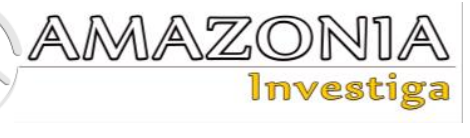

The philosophy of economics with its ICT revolution is about the ability to use reason, intelligence, nanotechnology, artificial intellect, robotics, robotization and automation to solve economic problems and achieve the sustainability of society. Therefore, the philosophy of economics, as the philosophy of digital civilization, was formed under the influence of the ideals of the "new Enlightenment 2.0", which is undoubtedly an important part of the ongoing discussion about the technological breakthrough. It is important to address the problems that humankind has faced with, both old and new, driven by a technological breakthrough. This situation provides an incredible opportunity for society to take advantage of, to catch up and spread the trends of new thinking that have resulted in the trends of the modern world, as already noted informatization, digitization, robotization, information security in modern society (Getman, Danilyan, Dzeban, Kalinovsky, Hetman, 2019, p. 6-14).

Economic synergies as a methodological basis of digital economy - a new scientific direction of philosophy of economics. The subject of economic synergy is the analysis of the economic phenomena of the information-digital society in terms of anthropologic-humanistic and synergistic activities. The object of studying the digital economy as a new scientific direction of the philosophy of economics is the processes of informatization, digitization, digitalization as complex and contradictory processes about a man, nature, society as a whole.

Any economic phenomena includes a set of cultural, human, mental, information-innovative dimensions of reality, interaction of competition and cooperation, search for ways of finding selforganization through the interaction of three factors - thesaurus, detector and selector. All this is manifested in the thesaurus of the economic information-digital system, which is non-linear and goes to self-organization, which also requires the development of a new conceptual and categorical apparatus - the self-organized information economy (Global Modernities, 2013).

Information technologies that influence the development of the digital economy as a new scientific direction in the philosophy of economics. It should be noted that modern breakthrough technologies, including robotics, nanotechnology, artificial intellect, synthetic biology, 3D-production, are the object of studying the philosophy of economics. The global information society is connected to the Internet with a trillion new devices, installations, facilities that connect people with constant communications and signal about "technological breakthrough". Power grids, gas and oil pipelines, traffic control systems, stock market, drinking water supply systems, street lighting, hospitals and sanitation systems - their functioning depends on technology and the Internet.

However, in this "wonderful new world" we have forgotten about a human and entrusted the base of civilization to machines. All these achievements should be revealed in the near future because they are capable of providing humanity with high well-being and prosperity. Each of these discoveries at this time keeps them in a secret, striking their destructive potential, because breakthrough technologies, on the one hand, bring progress to all of humanity, and on the other - bring unemployment, the dismissal of low-skilled workers and replacement them with robots, reducing a number of jobs as a result of the introduction of lean-production. That is why the place, role and importance of the digital economy as a new scientific direction of the philosophy of economics, is growing, the theoretical foundation of which we study, and on which we build our common future, which has a fragile nature and at any moment the "miracles" of technologies can turn against humanity, formation of sustainable digital economical concept: challenges, threats, priorities (Nikitenko Andriukaitiene \& Punchenko, 2019, p. 139-152). The analysis of the new foundations of digital economy as a new scientific direction in the philosophy of economics, which expands the possibilities of the "spirit / mind-body" dichotomy, has previously been restricted by both society and a human. Today, a human has dissolved in the information field of the digital economy, the "spirit / mind - body" of a human has been torn apart and alienated because of living in a world in which a human does not belong to himself and does not realize his immanent powers. A human has dissolved in a world of continuous information flow, which has engulfed a human and turned him into a chain in the general information-digital field and transformed into an "economic human", that prevails in a digital society, and human consciousness is determined by information and communication technologies, bits, algorithms of action (O'Reilly, 2018, p.223).

A human lives in an information-digitized world, which is no longer the product of the state, institutions and individuals, but the product of 
universal structures, techniques, finance, information and communications. The Internet has substantially changed the conditions of human development, new knowledge and rights of the central mediums have emerged concerning the human management, his consciousness, which have broken the substantial essence of a human into its separate components - "spirit", "mind", "body", giving birth even to an "artificial body" (Levitin, 2020, p.223). Therefore, it is necessary to move from a "rational person" to a socially adapted and adjusted person. Human nature contains much more than individualistic selfishness, which is imposed by the modern economic science. We are interconnected, interdependent, equal in our rights, adaptive social beings embedded in a single life network. The analysis of the new foundations of the digital economy as a new scientific direction of philosophy of economics has allowed to clarify the place and the role of a human in the information-digital and technological world, which is increasingly evolving and deepening the problems of human existence in this world because an artificial person, an artificial brain, an artificial consciousness and artificial body are coming to replace a real person, artificial consciousness and artificial body (new types of human beings emerged - "cyborg", "post man"). Technologies create an automation and robotization that pushes people away and replaces them with artificial machines, artificial intellect, artificial brains, supercomputer, various intricacies of artificial life, creation of computer programs that implement evolutionary processes and, as a consequence, creation of an artificial life (Mason Paul, 2019, p.120).

There is an opinion that people will soon be replaced by smart machines that will turn into the dominant form of life on the planet, that artificial intellect is already depleted and its next form is artificial life, in which the "spirit / mind-body" dichotomy is broken and artificial throughout. Undoubtedly, it should be agreed that information and computer technologies improve the economic essence of a human through computerization, automation, robotization, making it artificial, so, that the equivalent of the human mind and intellect also develops through the mechanisms of an artificial life (McAfee \& Brynolfsson, 2019, p.120).

Formation of creative person, creative class, creative art, creative intellect are the main problems of the digital economy as a new scientific direction of the philosophy of economics. Digital economy as a new scientific direction of the philosophy of economics in addressing the problems of the "spirit / mindbody" dichotomy reflects on many economic problems of the information society - economy, property, finance, economic freedom, consumption, economy values combined with culture and activity of a subject, its intellectual abilities move to the formation of creative class, creative art, creative intellect. This can be pointed out as the main problems of the digital economy as a new scientific direction of the philosophy of economics, which contributes to the formation of the creative values of the digital society. Solving the problems of the dichotomy "spirit / mind - body", a man is faced with the task to create, unite, form a single integrity, in which the dichotomy "spirit / mind - body" will be holistic, not broken apart, and new forms of this unity will be required, which will be dominated by creativity that unites the three broken parts of a man into one, human Capital for Digital Education (Klochkova, Ledneva, Sadovnikova, Darda, \& Oveshnikova, 2019, p.28-37).

Therefore, we conclude that creativity as a key construct in solving the problems of the digital economy as a new scientific direction in the philosophy of economics will not only reveal the need for the "spirit / mind-body" dichotomy, but turn it into integrity. Therefore, digital economy as a new scientific direction of philosophy of economics plays a fundamental role in transforming the economy, ordering it because it includes a wide reservoir of unused a human potential that will help to restore, revive, reunite of disparate parts "spirit", "mind", "mind", and complement the digital economy by a human as its object and subject, which will lead not only to the restoration of a human integrity, but also to the integrity of society, nature, economy as a whole (Reinert, 2018, p.17).

\section{Conclusions}

Thus, the theoretical and practical foundations of the digital economy as a new scientific direction, which develops in the context of the philosophy of economics, based on an interdisciplinary approach and combines many sciences philosophy and economics, politics and ecology, religion and morality and defines peculiarities of functioning of economic phenomena and processes in the dynamic and chaotic world of globalization 4.0, which has come to a new level and integrates all types and levels of globalization - economic, political, cultural. Digital economics, as a new scientific direction emerging in the context of the philosophy of 


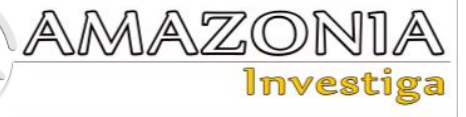

economics, destroys the old order and the old rules of industrial and post-industrial society game. Today, in the Internet, as a living economic, social and cultural organism, 7 billion united people with their brains, intellect, consciousness, who have already formed the "brain of the world" (Voronkova, Kyuvliuk. \& Olexenko, 2018, p.14-13).

Teillard de Chardin called this phenomena the noosphere or space of thought, mind, intellect, and today, along with the collective mind of machines, the intellect of nature, combined with the active human activity and their behavior, it was created a thing which the modern scientists called the "cholos". Today, there are 4 billion mobile phones and 2 billion computers combined in an external layer that encircles the Earth planet. Billions of peripheral chips and related devices - from cameras to cars and satellites should be added to them. Already in 2015, 15 billion devices were connected to the network, each of them contains one to four billion transistors, so "cholos" operates on a sextillion transistors.

Therefore, we can assume that the abovementioned transistors are neurons of the huge brain. In comparison, the human brain has about 86 billion neurons, or a trillion times less than "cholos". These dimensions are still not yet realized by humankind, but it is the basis our life and the dichotomy "human / mind - body" will be based on, and the large global information system is not a utopia, but our real life (Visit, 2018).

\section{Practical recommendations}

1. There is a need for the further development of information technology and the digital economy that contributes to the technological breakthrough and enhancement of the place and the role of a human in a digital society that needs a holistic person rather than a person separated to "spirit", "mind" and "body".

2. It is necessary to analyze the best traditions of the digital society represented by highly industrialized countries as well as to expand the scientific knowledge of the digital economy as a new scientific direction which is developing in the context of the philosophy of economy and to extrapolate and introduce the best traditions of the digital economy into our lives constantly, shaping the digital culture, digital consciousness, digital human.

3. Therefore, the analysis shows that a new digital culture and new digital thinking, capable of being implemented in system dynamics, should be formed; to develop global thinking in the categories of complex systems through which it is possible to adapt to changes in the environment; to develop the systemic, structural and adaptive thinking necessary to master the functions of a global manager and work at the level of global governance.

\section{References}

Andriukaitiene, R., Ernestas, J. \& Voronkova, V. (2019). The concept of corporate social responsibility and its implementation in the activity of organizations. Humanities Bulletin of Zaporizhzhe State Engineering Academy: Proceedings Scientific publications. 76, 184-196.

Brinolfsson, E. \& Makafi, E. (2016). The Second age of machines: work, progress and prosperity in the times of emergency technologies. Kiev: FUND, 2016. $236 \mathrm{c}$.

Cherep, A., Voronkova, V., Muts, L. \& Fursìn, A. (2019). Information and innovation technologies as a factor of improving the efficiency of digital economy and business in the globalization 4.0. HUMANITIES STUDIES: Proceedings Scientific publications. Issue 1. Zaporizhzhia: ZNU. 1 (78). 169-180.

Come On! (2019). Capitalism, shortsightedness, population and the destruction of the planet. Report to the Roman Club / Ernst Ulrich von Weizseker, Anders Wykman; translation from English by Y. Sirosh; for science. ed. V. Vovka, V.Butka. K.: Summit Book. 276 p.

Getman, A., Danilyan, O., Dzeban, A., Kalinovsky, Y., \& Hetman, Y. (2019). Information security in modern society: Sociocultural aspects. Amazonia Investiga, 9 (25), 6-14. Retrieved from

https://amazoniainvestiga.info/index.php/amazo nia/article/view/1021

Global Modernities (2013) / Ed. Mike Featherstone, Scott Leshach and Roland Robertson / trans. from English. Taras Tsymbala. K: Nika-Center. 400 p.

Goodman, Mark (2019). Crimes of the Future / Trans. from English. I. Mazarchuk, Y. Mashiko. Kharkov: «Ranok» Edition: Fabula. 592 p.

Kate's Report (2019). Donut Economy. How economists of the 21 st century see the world. K. Our format. 296 p.

Klochkova, E., Ledneva, O., Sadovnikova, N., Darda, E., \& Oveshnikova, L. (2019). Human Capital for Digital Education. Amazonia Investiga, 8(24), 28-37. Retrieved from 
https://amazoniainvestiga.info/index.php/amazo nia/article/view/947.

Kyvliuk, O., Andriukaitiene, R., Voronkova, V.\& Nikitenko, V. (2018). Sustainable Development of Organizations. Innovative Approach and Social Responsibility // Multiple regularity of security categories - crossdimension - (tom 1). Edited by Kamil Sygidus Pawel Lubinski Denys Svyrydenko. OlsztynKijov. 63-75. ISBN 978-83-947862-5-0

Levitin Daniel (2020). Structured thinking. A clear mind in information chaos / trans. from English. Roman Shiyan. K: Our format. 456 p.

Mamatov, A., Konstantinov, I., Mashkova, A., \& Savina, O. (2019). Information support system for regional human resource development. Amazonia Investiga, 7(17), 426-432.

Mason Paul (2019). Post-capitalism. A guide to the future / trans. from English. Natalia Mochalova. K: Our format.360 p.

McAfee Andrew \& Brynolfsson Eric (2019). Machine, platform, crowd. How to Tame Our Future / Trans. from English by Alexander Astashov. K: Our format. 336 p.

Nikitenko V., Andriukaitiene R. \& Punchenko O. (2019). Formation of sustainable digital economical concept: challenges, threats, priorities. HUMANITIES STUDIES: Proceedings Scientific publications. Issue 1. Zaporizhzhia: ZNU. 1 (78). 139-152.

O'Reilly Tim (2018). Who knows what the future will be like / Trans. from English. Yulia Kuzmenko. K. Our format.448 p.
Pinker Stephen (2019). Enlightenment today. Arguments in favor of reason, science and progress. Kyiv: Our format. 560 p.

Reinert Eric S. How Rich Wealth Enriched.... and why poor countries remain poor / Trans. from English. Petro Tarashchuk. Kiev: Tempora, 2018. 452 p.

Sadovnicova, L., \& Kokiel, A. (2020). Situational and Normative Approach as a Method for Identifying and Improving Business and Personal Qualities of a Manager. Amazonia Investiga, 9 (25), 153-159.

Tsvetkov, V., Shaytura, S., Feoktistova, V., Minitaeva, A., Kozhaev, Y., \& Belyu, L. (2020). Metamodelling in the information field. Amazonia Investiga, 9(25), 395-402. Retrieved from

https://amazoniainvestiga.info/index.php/amazo nia/article/view/1085

Visit Sandra (2018). Superhabs. How financial elites and their networks control the world // Trans. from English by Lesiya Stakhaniv and Sergei Gritsaenko. Kyiv: Yakaboo Publishing. $368 \mathrm{p}$.

Voronkova, V., Kyuvliuk, O. \& Olexenko, R. (2018). Metodology and organization of scientific researches in the field of socialhumanitarian sciences. Modern Management: Logistics and Education Opole: Tne Academy of Management and Administration. 14-22. 